\title{
Evaluation and Comparison of Some Parameters in Four Garlic Varieties
}

\section{Selen $\mathrm{AKAN}^{1 *}$}

\begin{abstract}
This research is aimed to determine the variation and identification of some morphological and biochemical parameters among different garlic varieties. In this research, three foreign hardneck (French, Spanish, Chinese) and one Turkish softneck garlic varieties have been studied. The investigated traits are included the bulb and clove weight, clove height, number of clove/bulb, color values ( $\mathrm{L}, \mathrm{a}, \mathrm{b}), \mathrm{pH}$, titratable acidity (TA), total soluble solids (TSS), dry matter (DM), total phenolic content (TPC) and antioxidant activity (AA). It is possible to say that varieties were significantly different on the basis of all morphological characters. The results indicated that Turkish variety had the highest TA (1.21\%), TSS (36.80\%) and AA (62.58\% I) and the highest DM was obtained from French variety. Meanwhile, Spanish and Chinese varieties have higher L values (88.15 and 87.24) than others. On the other hand the highest level of TPC (32.17 $\left.\mathrm{mg} \mathrm{GAE} \mathrm{g}^{-1} \mathrm{FW}^{-1}\right)$ was found in Chinese variety. In accordance with correlation analysis, there was a statistically significant correlation between TSS and $\mathrm{TA}$, and also TPC was significantly correlated with $\mathrm{pH}$ and TA $(\mathrm{p} \leq 0.05)$. The result will be helpful for the future studies to understand the similarities and differences of this 4 varieties of morphological and biochemical properties. This study will be good to repeat the experiment at multi variations grown worldwide. However, further studies should be done in this respect in the coming years.
\end{abstract}

Keywords: Garlic, bulb, morphologic character, biochemical quality

${ }^{1}$ Selen AKAN (Orcid ID: 0000-0002-2452-6483), Ankara University, Faculty of Agriculture, Horticulture Department, Ankara, Turkey

*Sorumlu Yazar / Corresponding Author: Selen AKAN, e-mail: selenakan2@gmail.com

Geliş tarihi / Received: 19.03.2019

Kabul tarihi / Accepted: 15.07.2019 


\section{INTRODUCTION}

Garlic is one of the first cultivated Allium species. The origin of the garlic is northwestern side of the Tien Shan Mountains and moved from here to Central Asia, Africa, Europe and America nearly 10.000 years ago (Etoh and Simon, 2002; Ipek et al., 2008). China is the main garlic producer and exporter country in the world. It's production is 22.160.465 tonnes and Turkey ranks the thirteenth (148.133 tonnes) country in the world for garlic production (FAO, 2017).

Garlic has known since ancient Egypt and it's cultivation is estimated that has been done for 5000-6000 years (Ipek et al., 2008). Currently, there are about 600 garlic varieties worldwide (Anonymous, 2018). There are about 36 different garlic genotypes around the Turkey (Turkes, 1978). The most common variety of garlic is called 'Taşköprü' rich in soluble solids content, ascorbic acid, minerals, aroma components, antioxidant activity and sulfur compounds (Artik and Poyrazoglu, 1994). Although it is propagated asexually, large scale morphological and agronomic diversity have been observed in garlic (Figliuolo et al., 2001). The morphological and genetic variations are great different in most of garlic characteristics (bulb weight, bulbing ratio, T.S.S and storability) among garlic genotypes (Osman and Abd El-Hameid, 1990; Gad El-Hak and Abd El-Mageed, 2000).

Garlic is classifed into two types, one of them is softneck (Allium sativum sub var. sativum) and the other one is hardneck (Allium sativum sub var. ophioscorodon). Softneck garlics have economical importance, numerous smaller cloves, a high number of protective shells, and a pungent odour, beside hardneck has a green stalk, or "scape," in the spring and larger cloves. However, hardneck varieties are stored for shorter than softneck varieties. The farmers prefer hardneck garlic for growing, with a larger, bright bulbs and cloves. And also, it is demanded by consumers because of it's easy peel.
Some quality parameters of garlic bulb are color, $\mathrm{pH}$, soluble solids content, moisture, reducing sugar content, firmness. These are so important in terms of consumer preferences (Pardo, 2007). Quality of garlic is effected by many factors such as variety, ecological factors, sulfur, nitrogen and selenium contents in the soil, growing temperature, cultivation method, storage temperature and storage time. Also, color of garlic bulb can range from white to red, purple or pink.

We utilized from garlic in terms of nutrition and health benefits. Antioxidant activity of garlic is very important because, it is relate to many therapeutic effects such as antithrombotic, antiaging, cardiovascular protection and cancer prevention (Huang et al., 2015). Meanwhile, the strong correlation was found between antioxidant activity and total phenolics content (Chen et al., 2013). Additionally, Kyung (2012) reported that there was a correlation between total phenolics, flavonoids content and antioxidant activity.

There have been few studies on the biochemical compounds of garlic based on foreign both hardneck and softneck varieties. So the major aim of this study was to determine similarities and compare differences among four garlic varieties according to their morphological and biochemical properties.

\section{MATERIALS AND METHODS}

\section{Plant Material}

This research was conducted in 2017 in laboratory at Department of Horticulture Faculty of Agriculture, Ankara University in Ankara, Turkey. Four foreign garlic varieties (V1: French, V2: Spanish, V3: Chinese and V4: Turkish) were obtained from 4 different region at mature stage.

The bulbs were imported from France, Spain and China to Turkey in 2017 harvest season (early and late June) from growers by transportation (Table 1). French (V1) variety was grown in East of France (Nice). Bulbs of Spanish (V2) garlic cultivar called 'Ajo Spring Blanco' 
was grown in Bigastro province in south of Spain. Chinese (V3) type was purchased from Shandong (coastal province of China). Turkish (V4) garlic
'Taşköprü' originated from Taşköprü district in Black Sea Region, Northern part of Turkey.

Table 1: Description of the varieties regarding location, latitude, longitude and elevation.

\begin{tabular}{lcccc}
\hline Varieties & Location & Latitude (N) & Longitude (E) & Elevation (m) \\
\hline French (V1) & Alsace & $48^{\circ} 19^{\prime} 5^{\prime \prime}$ & $7^{\circ} 26^{\prime} 29^{\prime \prime}$ & 1426 \\
Spanish (V2) & Bigastro & $38^{\circ} 03^{\prime} 47^{\prime \prime}$ & $0^{\circ} 53^{\prime} 44^{\prime \prime}$ & 24 \\
Chinese (V3) & Shandong & $36^{\circ} 05^{\prime} 54^{\prime \prime}$ & $120^{\circ} 22^{\prime} 18^{\prime \prime}$ & 1545 \\
Turkish (V4) & Taşköprü & $41^{\circ} 30^{\prime} 50^{\prime \prime}$ & $34^{\circ} 12^{\prime} 53^{\prime \prime}$ & 553 \\
\hline
\end{tabular}

Three of the selected genotypes (V1, V2 and V3) belong to hardneck type (Allium sativum sub var. ophioscorodon) and the other one (V4) belongs to softneck type (Allium sativum sub var. sativum). The bulb characteristics for those varieties and the main descriptors of morphological characteristics are shown in Table 2. Morphological characteristics were measured according to the International Union for the Protection of New Varieties of Plants (UPOV, 2001). Thus, eight traits were investigated.

Table 2: Main descriptors of morphological characteristics.

\begin{tabular}{lcccc}
\hline Properties & V1 & V2 & V3 & V4 \\
\hline Skin color of bulb & white & white & white & cream \\
Skin color of the clove & white & white & white & brown \\
Clove color of flesh & yellowish & yellowish & yellowish & yellowish \\
Distribution of cloves & radial & radial & radial & non-radial \\
Compactness of cloves & medium & medium & compact & compact \\
Anthocyanin stripes on dry external scales on bulb & present & absent & present & present \\
Anthocyanin stripes on dry external scales on clove & present & present & present & present \\
External cloves of bulb & absent & absent & absent & present \\
\hline
\end{tabular}

\section{Assessments}

Clove weight was measured with digital scales (Mettler Toledo) and heights were recorded with the help of digital Vernier $(150 \mathrm{x}$ 0.02 millimeter). The number of cloves/bulb were counted manually. Garlic was peeled by hand and stored at room conditions $\left(20 \pm 2{ }^{\circ} \mathrm{C}\right)$ until used.

Color measurements were done with a chromameter (Minolta CR-200) using the CIE L, a, b color space system and L (Lightness), a (green-red) and b (blue-yellow) values were examined in this study. Dry matters (DM) were analyzed by drying triplicate $5 \mathrm{~g}$ garlic cloves (AOAC, 1984). pH values were determined with using MilliporeSigma Color $\mathrm{pH}$ ast ${ }^{\circledR} \mathrm{pH}$ Test Strip Assortment. Garlic samples were dilueted with distilled water $(1 / 10 \mathrm{w} / \mathrm{v})$. Then, the strip was dipped into the sample tube for 3 seconds and then taken out from the sample solution and excess water was removed by shaking of strip. The strip placed on a clean and dry surface. After 5 minutes, the color was matched with the color scale of the product for determine the $\mathrm{pH}$ value. Total soluble solids (TSS) (\%) was measured by Abbe refractometer (Leica). Titratable acidity (TA) was determined in squeezed garlic juice by using an automatic titrator (DL 50 Mettler 
Toledo) and results were given as citric acid percentage.

Antioxidant activity (AA) was determined as DPPH radical scavenging activity using the method of Brand-Williams et al. (1995) with minor modifications. The percentage of inhibition reflects (Equation 1) how antioxidant compound are able to remove DPPH radical at the given time.

Inhibition $(\mathrm{I})(\%)=(($ Abs control- Abs sample $) /$ Abs control $) \times 100$

Total phenolics content (TPC) was analysed using the Folin Ciocalteu procedures based on the method described by Lu et al. (2011) and Akan et al. (2019) with minor changes. The absorbances were measured at $765 \mathrm{~nm}$ on a spectrophotometer (Shimadzu UV/VIS). TPC values were determined based on a gallic acid curve and results were given as mg of gallic acid equivalents/g freshweight (mg GAE $\mathrm{g}^{-1} \mathrm{FW}^{-1}$ ).

\section{Statistical Analysis}

All analyses were carried out in triplicate and five bulbs were used for each replication. Datas were expressed as means \pm standard error of mean. The statistical analysis of data was performed using one-way analysis of variance (ANOVA) and means were compared with Duncan's Multiple-Range Test at $\mathrm{p} \leq 0.05$ error level. Correlation matrix was done with using SPSS Professional Statistics (SPSS Inc., Chicago, IL).

\section{RESULTS AND DISCUSSION}

In this study, it was considered important to measure both morphologic and some biochemical properties of some garlic samples. Biometric parameters (Bulb and clove weight, clove height and clove numbers) per bulb are shown in Table 3 . These parameters were used to investigate and define the morphological differences among varieties. The variability between 4 genotypes is found statistically significant. Kaushik et al. (2016) explained the variation observed in morphological characters among the genotypes by the differences in genetically constituents as well as environmental effects.

Preliminary evaluations among 4 studied genotypes showed that the average bulb weights of V2 (77.02 g) was higher than V1 (67.93 g), V4 $(58.17 \mathrm{~g})$ and V3 (48.00 g), respectively (Table 3). We observed a statistically significant variation in bulb weight of these varieties. Differences in weight of the bulbs might be due to the environmental condition and genotype of garlic varieties. This is in agreement with results reported by Islam et al. (2007), Panse et al. (2013), Benke et al. (2018) and Yeshiwas et al. (2018).

Regarding clove weight, V1 samples show the highest value (9.58 g), followed by V2 (5.54 g) and V4 (4.07 g), respectively. The lowest clove weight (3.72 g) was obtained in V3 as seen in Table 3. There is a significant difference in clove weight of three different varieties of garlic cloves. These variations is thought to be due to the genetic variations among garlic varieties, as well as environmental sources and cultivation conditions. Our findings are higher than early findings of Baghalian et al. (2005), Grégrova et al. 2013 and Youssef et al. (2014).

The data concerning the mean values, results were shown that maximum clove height $(40.14 \mathrm{~mm})$ was noted in variety $\mathrm{V} 2$ followed by variety V1 $(36.17 \mathrm{~mm})$ and variety V3 (35.06 $\mathrm{mm})$, while minimum clove height $(34.84 \mathrm{~mm})$ was noted in V4 variety. All three varieties (V1, V3 and V4) are statistically a like to each other except variety V2 in clove height (Table 3). Our findings are higher than Singh and Chand (2003). Generally, our results are in accordance with Osman and Abd El-Hameid (1990), because these authors claimed that garlic genotypes from different parts of the world grown in different environments vary much in their clove size.

Number of cloves per garlic bulb ranged from 6 to 16. Significant variations were recorded among varieties with regard to the cloves number per bulb. The mean values indicate that a greater 
number of cloves/bulb (16.6) was recorded in V4 followed by V2 (14.0) and V3 (12.3), respectively (Table 3 ). While minimum number of cloves per bulb (6.6) was noted in variety V1. Meanwhile, the lowest number of cloves per bulb was recorded from the highest weight and height of cloves. These results were in agreement with earlier findings of Fikreyohhanis (2005), because author claimed that clove size had significant effects on the number of cloves per bulb. And also similar results confirmed by Hussein et al. (1995), Gad El-Hak and Abd El-Mageed (2000), Rahim et al. (2003), Islam et al. (2004), Zahedi et al. (2007) and Moustafa et al. (2009). These authors found that variations in bulb weights and number of cloves/bulb within their tested garlic genotypes.

Table 3: Comparison of four garlic varieties for biometric parameters.

\begin{tabular}{lcccc}
\hline Varieties & Bulb weight $(\mathbf{g})$ & Clove weight $(\mathbf{g})$ & Clove height $(\mathbf{m m})$ & Number of clove/bulb \\
\hline V1 & $67.93 \pm 0.95 \mathrm{~b}^{*}$ & $9.58 \pm 1.86 \mathrm{a}$ & $36.17 \pm 2.99 \mathrm{~b}$ & $6.66 \pm 1.15 \mathrm{c}$ \\
V2 & $77.02 \pm 3.83 \mathrm{a}$ & $5.54 \pm 0.39 \mathrm{~b}$ & $40.14 \pm 0.46 \mathrm{a}$ & $14.00 \pm 1.00 \mathrm{ab}$ \\
V3 & $48.00 \pm 0.30 \mathrm{~d}$ & $3.72 \pm 0.76 \mathrm{c}$ & $35.06 \pm 0.53 \mathrm{~b}$ & $12.33 \pm 2.51 \mathrm{~b}$ \\
V4 & $58.17 \pm 1.36 \mathrm{c}$ & $4.07 \pm 0.06 \mathrm{c}$ & $34.84 \pm 0.61 \mathrm{~b}$ & $16.66 \pm 0.57 \mathrm{a}$ \\
\hline LSD $(0.05)$ & 3.945 & 0.320 & 2.953 & 2.824 \\
\hline P. Value & 0.000 & 0.001 & 0.011 & 0.000 \\
\hline
\end{tabular}

*: mean \pm standard error of mean. ${ }^{1}$ Small letters show differences among varieties $\mathrm{P} \leq 0.05$.

Table 4 shows significance level among varieties on $\mathrm{L}, \mathrm{a}, \mathrm{b}, \mathrm{pH}$, TA (\%), TSS (\%) and DM (\%). The present study revealed that highest DM content (39.59\%) was observed in variety V1 and followed by V3 (39.36\%). Whereas, minimum DM content $(36.60 \%)$ was obtained in the clove V2 (Table 4). This might be due to the fact that larger sized cloves have more moisture content comparatively which results in higher physiological losses and ultimately lower percentage of dry matter content. DM contents were not significantly effected by varieties. Our results are higher than Artik and Poyrazoglu (1994) and Gautam et al. (2018). Similarly, our Chinese variety's results were higher than Pardo's et al. (2007) findings. But all DM results were lower than Singh and Chand (2003) and Singh et al. (2012) results.

Consumers prefer white bulbs of total soluble solids content ( $>35 \%$ in both cases) (Anonymous, 1997; USDA, 1997). TSS is used as an indicator of its storability (Foskett and Peterson, 1950). TSS results showed significant differences among garlic varieties (Table 4). This variation could be emerged from different environmental conditions. Total soluble solids content ranged from 33.13 to $36.80 \%$. Highest TSS was recorded in V4 (36.80\%) and the lowest value were recorded with 34.13 and $33.13 \%$ in V3 and V2, respectively. Our results gave much higher values than Pardo et al. (2007), Grégrova et al. (2013) and Youssef et al. (2014). On the other hand, our results are lower than early reports of Artik and Poyrazoglu, (1994), Singh and Chand, (2003) and Singh et al. (2012). Garlic genotypes grown in different environments vary much with their TSS.

Color is one of the most important quality characteristic in terms of consumer acceptance of garlic. Changes in L values were given in Table 4 , the highest results of the $\mathrm{L}$ values were found in V2 (88.15) followed by V3 (87.24) and V4 (84.85) and the lowest data was taken from V1 (73.54). Effects of variety for this parameter were not found statistically significant $(\mathrm{p} \leq 0.05)$. Table 4 revealed that the highest a value was recorded in V4 (-2.21) and lowest value was taken from V3 $(-3.14)$. Three of them were statistically similar 
but only V4 was found to be statistically different. Regarding $b$ values, statistically significant differences were attractive for all varieties. $b$ results were noted as 26.38, 21.33, 20.32 and 17.89 in V1, V3, V2 and V4, respectively. Our results $(\mathrm{L}, \mathrm{a}, \mathrm{b})$ were higher than varieties used by Rejano et al. (1997). Although, L and b vaues were found higher, a values were noticed lower than results of Artık and Poyrazoğlu (1994) and Pardo et al. (2007). Additionally, L and a values were lower, and $b$ values were higher than Grégrova et al. (2013).

Titratable acidity is a critical quality parameter in garlic. TA content were determined between 1.06-1.21\%. As regards TA, V4 (1.21\%) and V1 (1.19\%) were found to be highest, which were significantly different from the V2 (1.07\%) and V3 (1.06\%) (Table 4). Our results are higher than reports of Artik and Poyrazoglu (1994), Dronachari et al. (2010) and Akan (2016). Considering TA, it is an important parameter for freshness, mature stage, flavor and microbial quality.

To evaluate the quality of garlic and garlic products, it is important to consider $\mathrm{pH}$ levels. Generally, pH level may influenced mainly by irrigation, fertilization and ecological conditions. Based on our $\mathrm{pH}$ results in Table 4, higher values were found in V4 and V3. V1 showed the lowest $\mathrm{pH}$ level. When comparing $\mathrm{pH}$ levels among varieties, significant difference was only for V1. In all cases, pH level was between 5.50 and 6.33. Some early reports (Artik and Poyrazoğlu, 1994; Pardo et al., 2007) were found higher than our results.

AA in varieties ranges from $42.62 \%$ I to $62.58 \%$ I. Varieties V4 $(62.58 \%$ I) and V3 (42.62\% I) exhibiting a high and low antioxidant activity, respectively. AA was found statistically different among varieties (Figure 1). Our findings were higher than Queiroz et al. (2009), Priecina and Karlina (2013) and Kavalcová et al. (2014), Ghasemi et al. (2015). According to these results, it seems that the level of AA in garlic has been affected by geographical area. Additionally, Strail et al. (2006) and Bozin et al. (2008) stated that the reason for this may be the experimental method, the polarity of the garlic extracts and the content of the different phenolic compounds it contains.

TPC results of four garlic varieties are seen in Figure 1. Significant differences were not observed among varieties, the highest value of TPC was recorded in V3 (32.17 $\mathrm{mg} \mathrm{GAE} \mathrm{g}^{-1} \mathrm{FW}^{-}$ $\left.{ }^{1}\right)$, and also variety $\mathrm{V} 1$ (26.11 $\mathrm{mg} \mathrm{GAE} \mathrm{g}^{-1} \mathrm{FW}^{-1}$ ) has the lowest TPC values (Figure 1). Generally, very small variations were found in TPC between different garlic varieties. Regarding TPC content, results were higher than Bozin et al. (2008), Queiroz et al. (2009), Beato et al. (2011) Priecina and Karlina (2013), Kavalcová et al. (2014) and Petropoulos et al. (2018) findings, but lower trend was observed in varieties of Nagella et al. (2014) and Ghasemi et al. (2015) used in their study. However, these higher results from earlier findings are most probably due to genotype and different region effect, cultivation practices and climatic conditions beside differences in the methodology and the experimental conditions used in the different studies.

Correlation matrix was also done to determine the relationships among different parameters in this study. Simple correlation was done on analysed parameters of different garlic varieties (Table 5). TSS was positively and significantly correlated with TA, DM and L value were non-significantly correlated with other parameters. a value was significantly correlated with TA; b value was significantly correlated with $\mathrm{pH}, \mathrm{L}$ and a value. Significant positive correlation of AA was observed with a value. Also, TPC was significantly correlated with $\mathrm{pH}$ and TA. 
Table 4: Interaction effect of garlic varieties on L, a, b, pH, TA (\%), TSS (\%) and DM (\%).

\begin{tabular}{|c|c|c|c|c|c|c|c|}
\hline Var. & $\mathbf{L}$ & $\mathbf{a}$ & b & pH & TA & TSS & DM \\
\hline V1 & $73.54 \pm 2.94 *$ & $-3.01 \pm 0.19 b^{1}$ & $26.38 \pm 1.93 \mathrm{a}^{1}$ & $5.50 \pm 0.00 \mathrm{~ns}$ & $1.19 \pm 0.00 \mathrm{a}$ & $35.86 \pm 0.25 b$ & $39.59 \pm 1.35 \mathrm{~ns}$ \\
\hline V2 & $88.15 \pm 1.01 \mathrm{~ns}$ & $-2.93 \pm 0.27 b$ & $20.32 \pm 1.28 b$ & $6.16 \pm 0.57 \mathrm{~ns}$ & $1.07 \pm 0.00 \mathrm{~b}$ & $33.13 \pm 0.15 \mathrm{~d}$ & $36.60 \pm 0.16 \mathrm{~ns}$ \\
\hline V3 & $87.24 \pm 1.21 \mathrm{~ns}$ & $-3.14 \pm 0.43 b$ & $21.33 \pm 0.86 b$ & $6.33 \pm 0.28 \mathrm{~ns}$ & $1.06 \pm 0.10 \mathrm{~b}$ & $34.13 \pm 0.25 \mathrm{c}$ & $39.36 \pm 2.15 \mathrm{~ns}$ \\
\hline V4 & $84.85 \pm 0.24 \mathrm{~ns}$ & $-2.21 \pm 0.06 \mathrm{a}$ & $17.89 \pm 0.35 \mathrm{c}$ & $6.33 \pm 0.28 \mathrm{~ns}$ & $1.21 \pm 0.00 \mathrm{a}$ & $36.80 \pm 0.26 \mathrm{a}$ & $38.84 \pm 2.14 \mathrm{~ns}$ \\
\hline $\operatorname{LSD}(0.05)$ & - & 0.517 & 2.359 & - & 0.089 & 0.441 & - \\
\hline P. Value & 0.083 & 0.013 & 0.000 & 0.059 & 0.052 & 0.000 & 0.189 \\
\hline
\end{tabular}

*: mean \pm standard error of mean.

${ }^{1}$ Small letters show differences among varieties $(\mathrm{P} \leq 0.05)$.

ns: non significant

Table 5: Simple correlation on analysed parameters of different garlic varieties.

\begin{tabular}{|c|c|c|c|c|c|c|c|c|c|}
\hline Parameters & pH & TA & TSS & DM & $\mathbf{L}$ & $\mathbf{a}$ & b & $\mathbf{A A}$ & TPC \\
\hline pH & 1 & & & & & & & & \\
\hline $\mathbf{T A}$ & 0.152 & 1 & & & & & & & \\
\hline TSS & 0.526 & $0.005 *$ & 1 & & & & & & \\
\hline DM & 0.533 & 0.995 & 0.093 & 1 & & & & & \\
\hline $\mathbf{L}$ & 0.101 & 0.203 & 0.164 & 0.174 & 1 & & & & \\
\hline $\mathbf{a}$ & 0.640 & $0.029 *$ & 0.062 & 0.541 & 0.984 & 1 & & & \\
\hline b & $0.009 *$ & 0.917 & 0.920 & 0.246 & $0.013 *$ & $0.045^{*}$ & 1 & & \\
\hline $\mathbf{A A}$ & 0.187 & 0.464 & 0.253 & 0.830 & 0.857 & $0.041 *$ & 0.100 & 1 & \\
\hline TPC & $0.037 *$ & $0.010 *$ & 0.077 & 0.423 & 0.330 & 0.633 & 0.379 & 0.594 & 1 \\
\hline
\end{tabular}

* Significant at 0.05 probability level.
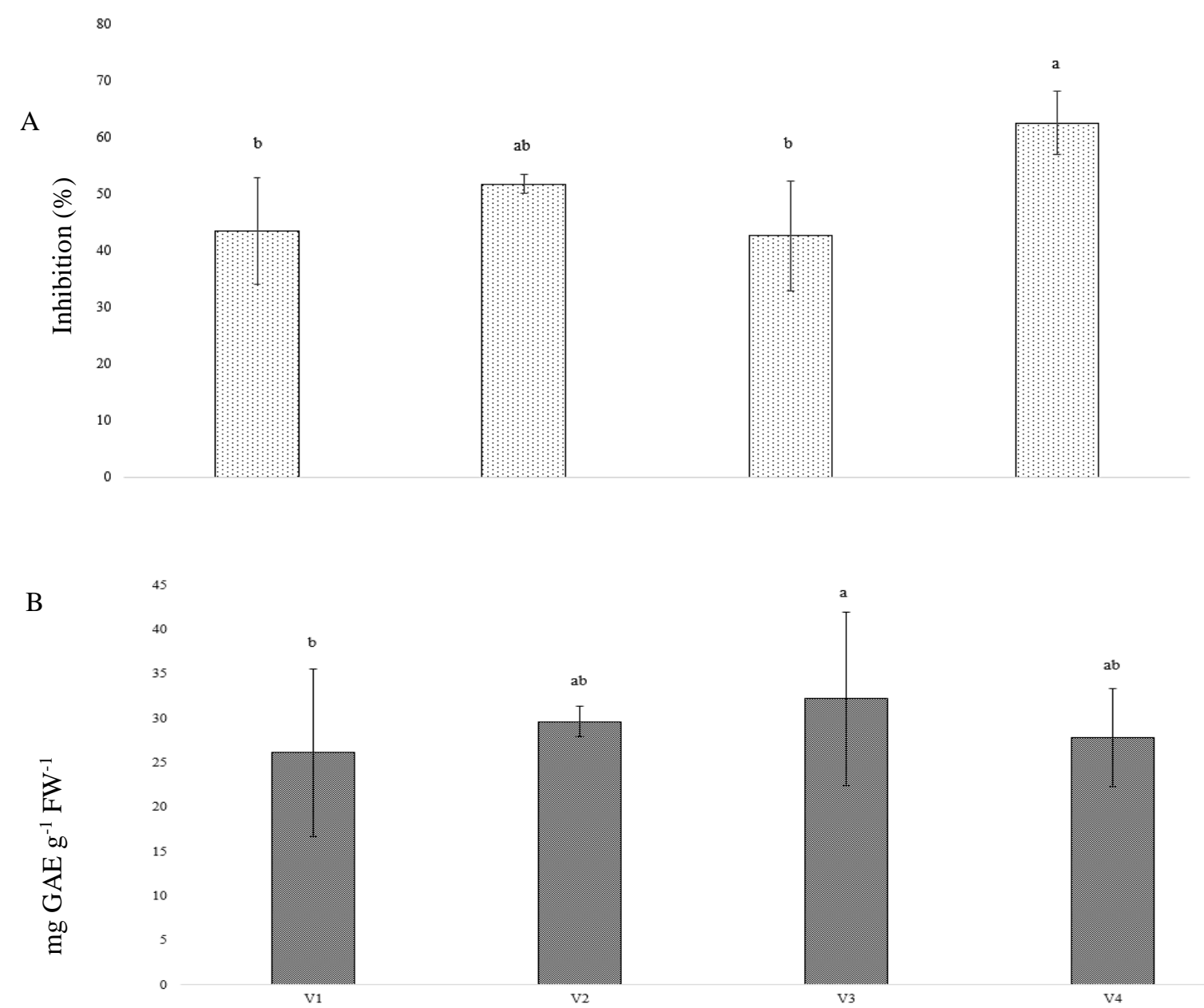

$\mathrm{v} 4$

Figure 1: Antioxidant activity (A) and total phenolics content (B) of four different garlic varieties. 


\section{CONCLUSION}

All analysis of the variability indicators in garlic varieties exhibited similar or dissimilar results. According to the our results, the effect of variety was significant for all morphological characters (Bulb weight, clove weight, clove height, number of clove/bulb). Meanwhile, lack of significant variation in some biochemical parameters can be explained by different genetic and environmental conditions.

Turkish cultivar (Taşköprü) variety V4 has great characteristics such as TA $(1.21 \%)$, TSS $(36.80 \%)$ and antioxidant activity $(62.58 \%$ I). On the other hand, imported cultivars can be considered promising cultivars because Spanish variety V2 and Chinese variety V3 bulbs have high L values (88.15 and 87.24), and also French varieties have highest DM (39.59\%) and additionally Chinese variety V3 has a highest level of TPC (32.17 mg GAE g $\left.\mathrm{g}^{-1} \mathrm{FW}^{-1}\right)$. Therefore, all these characteristics are preferred by garlic growers and consumers in whole world.

As a result, this study focused on influence of the different garlic varieties, which are cultivated from different regions, on some morphological and biochemical properties. Some findings in this work can be considered as an attractive by researchers, who are interested in garlic. Moreover, comparison of different varieties gives a chance to select the most valuable breeding material for future studies.

\section{REFERENCES}

Akan S, 2016. Effect of modified atmosphere packaging and methyl jasmonate treatment on postharvest physiology of Taşköprü Garlic. Ankara University, Agriculture Faculty (published) $\mathrm{PhD}$ thesis, $164 \mathrm{p}$.

Akan S, Tuna Gunes N, Yanmaz R, 2019. Methyl jasmonate and low temperature can help for keeping some physicochemical quality parameters in garlic (Allium sativum L.) cloves. Food Chemistry, 270: 546-553.
Anonymous, 1997. Commission Regulation (EC) No 2288/97 of 18 November 1997 Laying down marketing standards for garlic. Official Journal, 315: 3-6.

Anonymus, 2018. 400 Million Pounds of Garlic Grown in U.S. Annually. https://aghires.com/garlic-facts/. (access date: 20th February, 2019).

AOAC, 1984. Official methods of analysis of the association of official analytical chemists. The Association of Official Analytical Chemists, Inc., Arlington, VA.

Artik N, Poyrazoglu ES, 1994. Kastamonu sarımsağının (Allium sativum L.) kimyasal bileşiminin belirlenmesi üzerine bir araştırma. Gıda Teknoloji Derneği Dergisi, 19(1): 3-9.

Baghalian K, Ziai SA, Naghavi MR, Naghdi Badi H, Khalighi A, 2005. Evaluation of allicin content and botanical traits in 1ranian garlic (Allium sativum L.) Ecotypes. Scientia Horticulturea, 103: 155-166.

Beato VM, Orgaz F, Mansilla F, Montaño A, 2011. Changes in phenolic compounds in garlic (Allium sativum L.) owing to the cultivar and location of growth. Plant Foods for Human Nutrition, 66: 218-223.

Benke AP, Dukare S, Mahajan V, Singh M, 2018. Genetic divergence studies for bulbing and related traits in garlic germplasm during kharif season. International Journal of Current Microbiology and Applied Sciences, 7(1): 2920-27.

Brand-Williams W, Cuvelier ME, Berset C, 1995. Use of a free radical method to evaluate antioxidant activity. Journal of Food Science and Technology, 28: 25-30.

Bozin B, Minica-Dukic N, Samojlik I, Giran A, Igic I, 2008. Phenolics as antioxidants in garlic (Allium sativum L., Alliaceae). Food Chemistry, 111(4): 925-929.

Chen S, Shen X, Cheng S, Li P, Du J, Chang Y, Meng $H, 2013$. Evaluation of garlic cultivars for polyphenolic content and antioxidant properties. Plos One, 8(11): 1-12. 
Dronachari M, Venkatachalapathy K, Rajashekarappa $\mathrm{K}$, 2010. Effect of pretreatments and packaging on shelf life of peeled garlic cloves. Jornal of Dairying Foods \& Home Science, 29(2):130135.

Etoh T, Simon PW, 2002. Diversity, fertility and seed production of garlic. In: Rabinowitch H.D. and Currah L. (eds) Allium Crop Science - Recent Advances. CABI Publishing, Wallingford, UK, $101-117 \mathrm{p}$.

FAO, 2017. http://www.fao.org/faostat/en/\#data/TP. (access date: 8th February, 2019).

Figliuolo G, Candido V, Logozzo G, Miccoli V, Spagnoletti-Zeuli PL, 2001. Genetic evaluation of cultivated garlic germplasm (Allium sativum L. and A. ampeloprasum L.). Euphytica, 121: 325-334.

Fikreyohannes G, 2005. Effects of clove weight and plant density on the bulb yield and yield components of garlic (Allium sativum L.) in Awabel Woreda, Eastern Gojam Zone. Alemaya University, Ethiopia, MSc. thesis, $57 \mathrm{p}$.

Foskett RL, Petersen CE, 1950. Relation of dry matter content to storage quality in some onion varieties and hybrids. Proceeding of the American Society for Horticultural Science, 55: 314-318.

Gad El-hak SH, Abd El-Mageed YT, 2000. Effect of nitrogen sourcen an growth, yield nitrate content and storage ability of two garlic cultivars. El-Minia Journal of Agricultural Research and Development, 20: 115-139.

Gautam N, Kanwar HS, Mehta DK, Kansal S, Kumar S, 2018. Effect of clove weight and plant growth regulators on shelf-life of garlic (Allium sativum L.). Journal of Pharmacognosy Phytochemistry, 7(2): 1696-1700.

Ghasemi K, Bolandnazar S, Tabatabaei SJ, Pirdashti H, Arzanlou M, Ebrahimzadeh MA, Fathi H, 2015. Antioxidant properties of garlic as affected by selenium and humic acid treatments. New Zealand Journal of Crop and Horticultural Science, 43: 173-181.

Grégrova A, Č́ížková H, Bulantová I, Rajchl A, Voldřich M, 2013. Characteristics of garlic of the czech origin. Chech Journal of Food Science, 31(6): 581-588.
Huang CH, Hsu FY, Wu YH, Zhong L, Tseng MY, Kuo CJ, Chiou SH, 2015. Analysis of lifespanpromoting effect of garlic extract by an integrated metabolo-proteomics approach. The Journal Nutritional Biochemistry, 26(8): 808817.

Hussein NS, El-Saeid HM, Omar EA, 1995. Development of growth and yield of some lines of chinese garlic. Egyptian Journal of Horticulture, 22(1): 19-23.

Ipek M, Ipek A, Simon PW, 2008. Molecular characterization of kastamonu garlic: An economically important garlic clone in Turkey. Scientia Horticulturae, 115(2): 203-208.

Islam MJ, Islam MA, Akter Tania S, Saha SR, Alam MS, Hasani MK, 2004. Performance evaluation of some garlic genotypes in Bangladesh. Asian Journal of Plant Sciences, 3(1): 14-16.

Islam MJ, AK M, Hossain M, Khanam F, Majumder UK, Rahman MM, Rahman MS, 2007. Effect of mulching and fertilization on growth and yield of garlic at Dinajpur in Bangladesh. Asian Journal of Plant Sciences, 6(1): 98-101.

Kavalcová P, Bystrická J, Tomáš J, Karovičová J, Kuchtová V, 2014. Evaluation and comparison of the content of total polyphenols and antioxidant activity in onion, garlic and leek. Potravinarstvo Scientific Journal for Food Industry, 8(1): 272-276.

Kaushik S, Kumar M, Prakash S, Kumar V, Kumar Singh M, Singh B, Malik S, Singh K, 2016. Study of genetic diversity in garlic (Allium Sativum L.) by using morphological characters. Progressive Agriculture, 16(2): 204-210.

Kyung KH, 2012. Antimicrobial properties of allium species. Current Opinnion in Biotechnology, 23: $142-147$.

Lu X, Ross CF, Powers JR, Aston DE, Rasco BA, 2011. Determination of total phenolic content and antioxidant activity of garlic (Allium sativum) and elephant garlic (Allium ampeloprasum) by attenuated total reflectancefourier transformed infrared spectroscopy. Journal of Agricultural and Food Chemistry, 59: 5215-5221. 
Moustafa YMM, Latif SS, Abd El Naem GF, Fouly $\mathrm{HMH}$, Ahmed SI, 2009. Performance of new imported foreign garlic genotypes grown under the egyptian conditions. Egyptian Journal of Agricultural Research, 87(1): 219-241.

Nagella P, Thiruvengadam M, Ahmad A, Yoon JY, Chung IM, 2014. Composition of polyphenols and antioxidant activity of garlic bulbs collected from different locations of Korea. Asian Journal of Chemistry, 26(3): 897-902.

Osman AZ, Abdgar El-Hameid AM, 1990. Evaluation of eighteen ecotypen of egyption garlic. Minia Journal of Agricultural Research and Development, 12: 1625-1640.

Panse R, Jain PK, Avneesh G, Singh DS, 2013. Morphological variability and character association in diverse collection of garlic germplasm. African Journal of Agricultural Research, 8(23): 2861-2869.

Pardo JE, Escribano J, Gómez J, Alvarruız A, 2007. Physical-chemical and sensory quality evaluation of garlic cultivars. Journal of Food Quality, 30(5): 609-622.

Petropoulos S, Fernandes Â, Barros L, Ciric A, Sokovic M, Ferreira IC, 2018. Antimicrobial and antioxidant properties of various Greek garlic genotypes. Food Chemistry, 245: 7-12.

Priecina L, Karlina D, 2013. Total polyphenol, flavonoid content and antiradical activity of celery, dill, parsley, onion and garlic dried conventive and microwave-vacuum dryers. $2^{\text {nd }}$ International Conference on Nutrition and Food Sciences, 107-112p, Singapore.

Queiroz YS, Ishimoto EY, Bastos DH, Sampaio GR Torres EA, 2009. Garlic (Allium sativum L.) and ready-to-eat garlic products: In vitro antioxidant activity. Food Chemistry, 115(1): 371-374.

Rahim MA, Chowdhury MNA, Anwar HRMM, Alam MS, 2003. Effect of planting dates on the growth and yield of garlic germplasm. Asian Journal of Plant Sciences, 2(2): 171-174.

Rejano L, Sánchez AH, De Castro A, Montaño A, 1997. Chemical characteristics and storage stability of pickled garlic prepared using different processes. Journal of Food Sciences, 62(6): 1120-1123.
Singh Y, Chand R, 2003. Performance studies of some garlic (Allium sativum L) clones. Himachal Journal of Agriculture Research, 29(1-2): 3542.

Singh RK, Dubey BK, Bhonde SR, 2012. Studies on some genotypes for yield, quality and storage in garlic. SAARC Journal of Agriculture, 10(2): 165-170.

Strail P, Klejdus B, Kuban V, 2006. Determination of total content of phenolics compounds and their antioxidant activity in vegetables-evaluation of spectrophotometric methods. Journal of Agricultural and Food Chemistry, 54(3): 607616.

Turkes N, 1978. Türkiye sarımsaklarının seleksiyon yolu ile 1slahı üzerine araștırmalar, Ankara University, Agriculture Faculty, (published) $\mathrm{PhD}$ thesis, 314p.

USDA, 1997. United States Standards for Grades of Garlic.

http://www.ams.usda.gov/standards/garlic.pdf. Accessed Date: 19/12/2018.

UPOV, 2001. Guidelines for the conduct of tests for distinctness, uniformity and stability. Garlic (Allium sativum L.), Geneva.

Yeshiwas Y, Belete N, Tegibew W, Yohaness G, Abayneh M, Kassahun Y, 2018. Collection and characterization of garlic (Allium sativm L.) germplasm for growth and bulb yield at Debre Markos, Ethiopia. Journal of Horticultural and Food Chemistry, 10(3): 17-26.

Youssef NS, Tony HS, 2014. Influence of different planting date on the performance of new garlic genotypes grown under El-Minia governorate conditions. Journal of Nature and Science, 12(5): 47-54.

Zahedi B, Kashi AK, Zamani Z, Mosahebi GH, Hassani M, 2007. Evaluation of Iranian garlic (Allium sativum L.) genotypes using multivariate analysis methods based on morphological characteristics. Biotechnology Journal, 6(3): 353-356. 